\title{
Procalcitonin in the diagnosis of sepsis and correlations with upcoming novel diagnostic markers
}

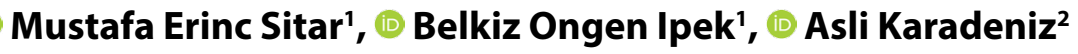 \\ 'Department of Medical Biochemistry, Maltepe University Faculty of Medicine Education Research Hospital Central Laboratory, \\ Istanbul, Turkey \\ ${ }^{2}$ Department of Infectious Diseases and Clinical Microbiology, Maltepe University Faculty of Medicine Education Research Hospital \\ Central Laboratory, Istanbul, Turkey
}

\begin{abstract}
Objectives: Sepsis is a complex and lethal condition. For successful treatment, clinicians need high quality testing to guide the approach to pathogen identification and treatment. Medical laboratories play a vital role in the detection of infectious agents, and must continually strive to discover new and reliable tests and to analyze the reliability of existing tests in different diseases and expand their usage as appropriate. Selecting the appropriate therapy, reducing the use of antibiotics and thereby reducing antibiotic resistance are also undeniable parts of this task. The most commonly used parameters to guide infection therapy are the white blood cell count, the erythrocyte sedimentation rate, the absolute count of neutrophils, the absolute number of lymphocytes, and the level of C-reactive protein, serum amyloid A protein, ceruloplasmin, haptoglobin, fibrinogen, and procalcitonin (ProCT). Although ProCT has been accepted as quite effective in differentiating serious bacterial infections, there are unresolved questions regarding effective usage during follow-up, as there are with other markers. ProCT and other promising biomarkers in a sepsis setting were the focus of this review, beginning with the first study to define ProCT in the literature, and examining some of the studies related to the importance of the ProCT-sepsis relationship, and detailed information on candidate markers.
\end{abstract}

Keywords: Biomarker, C-reactive protein, procalcitonin, reference interval, sepsis

In the early 1960s, Nobel laureate Frank Macfarlane Burnet I made an interesting observation that by the end of World War II it was possible to say that almost all of the major practical problems of dealing with infectious disease had been solved $[1,2]$. It can be considered an early outcome among the successes of the post-penicillin medical era. Unfortunately, in today's modern world, more than 700.000 people each year still face death due to antibiotic-resistant bacterial infections around the globe and this currently unpreventable burden is increasing exponentially [3]. International institutions like the World Health Organization, the US Centers for Disease Control and Prevention, and national policymaker institutions are all in this fight for the sake of human health. Continuing education of healthcare profes- sionals, public advertisements, changes in medical school curricula, state-of-the-art research, warnings to patients, signs in pharmacies, propagation of information about side effects, and institutional control mechanisms are all parts of a solution. Naturally, medical laboratories are also partners in this challenge. Medical laboratories make a huge contribution to medical decisions. The identification of diseasecausing agents; determining a definite diagnosis of infectious disease, resistance, and sensitivity to pharmaceuticals; and contributing to the follow-up and prognosis of disease are all duties of clinical laboratories. Highly sensitive and specific biomarkers are always in demand in order to prevent antibiotic overuse in the general population and to give clinicians a robust approach [4]. There is growing inter-

Address for correspondence: Mustafa Erinc Sitar, MD. Departmen of Medical Biochemistry, Maltepe University Faculty of Medicine Education Research Hospital Central Laboratory, Istanbul, Turkey

Phone: +90 5332143544 E-mail: merincsitar@maltepe.edu.tr ORCID: 0000-0001-5114-8660

Accepted Date: June 17, 2019 Available Online Date: June 11, 2019 Available Online Date: October 11, 2019

${ }^{\circ}$ Copyright 2018 by International Journal of Medical Biochemistry - Available online at www.internationalbiochemistry.com 
est in procalcitonin (ProCT), as well as some other biomarkers. An advanced search of PubMed publications conducted in March 2019 using the terms "procalcitonin" and "sepsis" yielded more than 2000 papers. This general search clearly demonstrates the clinical significance of ProCT. This review focuses on current and promising markers and their relationship to sepsis and ProCT.

\section{Procalcitonin and its significance in medical history}

The introduction of ProCT to the world of science dates back to the 1970s (Table 1). The first medical studies of ProCT were concentrated on tumors once its unique synthesis and structure were identified using radioimmune assays. It is the high-molecular-weight precursor of calcitonin, a hormone that is released from parafollicular cells (C cells) of the thyroid (Fig. 1). Subsequent studies in the 1980 s observed that ProCT was also released into systemic circulation in non-thyroid malignancies [5]. Researchers concluded that ProCT is a molecule synthesized by many types of cells in humans, but often occurs in response to tissue damage, such as a burn or neoplasm (Fig. 1). In a study of 79 pediatric patients conducted by Assicot et al. [6] in 1993, ProCT demonstrated a significant correlation with microbial invasion. They used a monoclonal immunoradiometric method to measure ProCT levels in blood. This critical clinical trial established the use of ProCT as an infection-based biomarker. Since the publication of this research, many studies based on bacterial, viral, and even parasitic infections have been published in reputable journals. The success of this study led to an avalanche of new research. ProCT has become an indispensable tool in the follow-up of bacterial infections in modern medical practice.

\section{Procalcitonin and sepsis}

Sepsis was defined as "life-threatening organ dysfunction due to a dysregulated host response to infection" by the Third International Consensus Definitions Task Force (Sepsis-3). This condition, which is among the most common causes of death in general hospitals, can progress silently. Additional definitions were subsequently developed to help determine organ dysfunction earlier in sepsis. The Quick Sequential Organ Failure Assessment (qSOFA) score uses 2 of 3 criteria to identify high-risk patients: Glasgow coma scale score $(\leq 13)$, systolic blood pressure $(\leq 100 \mathrm{mmHg})$, and respiratory rate ( $\geq 22 \mathrm{bpm}$ ). Septic shock is defined as a subset of sepsis, with the requirement of vasopressor therapy to sustain a mean arterial pressure of $\geq 65 \mathrm{mmHg}$, and serum lactate $>2 \mathrm{mmol} / \mathrm{L}$ without hypovolemia [15]. An early, robust, and definitive diagnosis is important; in addition to the clinical evaluation, laboratory work is extremely helpful in the management of sepsis $[16,17]$. Several biomarkers have been used for the diagnosis and prognosis of sepsis, but there is still no gold standard biomarker $[18,19]$. However, ProCT could be an important and prognostic marker for sepsis $[16,17]$. Following bacterial infection, the ProCT level rises in 6 to 12 hours and drops by $50 \%$ after 24 hours with the help of appropriate antibiotherapy and the work of the immune system. The level is not affected (does not decrease) by anti-inflammatory drugs [20]. ProCT appears to be a useful biomarker to differentiate bacterial infections from viral infections with high sensitivity and specificity rates. The reference range of ProCT is less than $0.1 \mu \mathrm{g} / \mathrm{L}$ in the healthy, non-pediatric population, though those limits change according to the specific pathology (Table 2) [21, 22]. A high ProCT level predicts severe sepsis and is correlated with inflammation severity. The higher the value in systemic circulation, the greater the severity of bacterial infection. ProCT levels have been observed to be higher in Gram-negative bacteremia compared with Grampositive bacteremia and fungal sepsis in some studies [18, 19]. One of these studies evaluating the rapid diagnosis of sepsis suggested that ProCT could be used to differentiate severe clinical situations like sepsis and septic shock, as well as to help determine the type of microbe [19].

Following approval in 2017 from the US Food and Drug Administration for the use of ProCT as a blood infection biomarker to guide antibiotic therapy in acute respiratory infections and sepsis, several studies demonstrated that

Table 1. Procalcitonin milestones in medical history

\begin{tabular}{lcc}
\hline Event & Date & Reference \\
\hline First definition and characterization experiments of calcitonin precursor named "procalcitonin" & 1974,1975 & {$[7,8]$} \\
Unusual synthesis of high-molecular-weight form of calcitonin detected in pulmonary tumor cell lines & 1978 & 1984 \\
Identification of entire preprocalcitonin 116 amino acid chain & 1984 \\
Isolation of procalcitonin from experimental thyroid neoplasms & {$[10]$} \\
Information about numerous extra-thyroid malignancies capable of biosynthesizing calcitonin precursors & 1989 \\
and first suggestion to use them as biomarkers & {$[11]$} \\
Detection of procalcitonin role in severe multi-systemic infections & 1993 \\
Elevation of procalcitonin level with no change in calcitonin level following experimental Gram-negative & 1994 \\
bacteria endotoxin application & {$[5]$} \\
Suggestion of procalcitonin use as a biomarker for septicemia in newborns & 1996 \\
High diagnostic value of procalcitonin during sepsis for immunocompromised patients reported & {$[12]$}
\end{tabular}




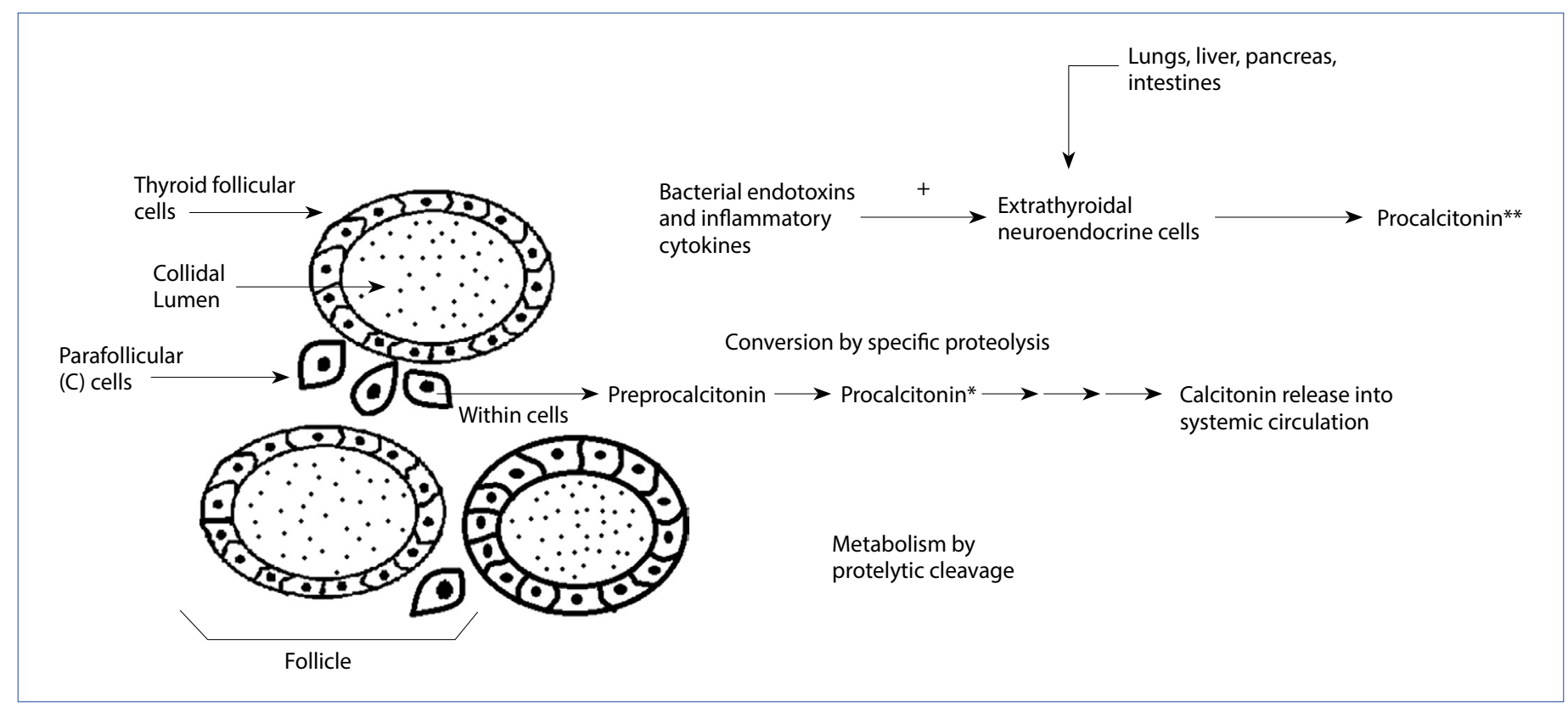

Figure 1. Procalcitonin synthesis from parafollicular cells $(\mathrm{C} \text { cells })^{*}$ and extra-thyroidal neuroendocrine cells ${ }^{* *}$ following tissue damage.

Table 2. Reference ranges for procalcitonin in different physiological and/or pathological states

\begin{tabular}{lll}
\hline Population type & Reference range or cut-off limits & Reference \\
\hline Healthy individuals (including geriatric patients) & Less than $0.1 \mu \mathrm{g} / \mathrm{L}$ & {$[22,23]$} \\
Pregnant women in good health during 1st and 2nd trimesters & $0.018-0051 \mu \mathrm{g} / \mathrm{L}$ (standard normal limits) & {$[24]$} \\
Preterm children (just at birth) & $0.01-0.56 \mu \mathrm{g} / \mathrm{L}$ (standard normal limits) & {$[25]$} \\
Term newborns (just at birth) & $0.01-0.55 \mu \mathrm{g} / \mathrm{L}$ (standard normal limits) & {$[25]$} \\
Pediatric patients who have community-acquired pneumonia & $2.06 \pm 0.60 \mu \mathrm{g} / \mathrm{L}$ (mean $\pm \mathrm{SD}$ ) & {$[26]$} \\
Sepsis patients older than 18 years of age & $5.66(0.98-21.2) \mu \mathrm{g} / \mathrm{L}$ (median level with extended limits) & {$[27]$} \\
Geriatric patients who have definitive bacteremia & $17 \pm 45 \mu \mathrm{g} / \mathrm{L}$ & {$[28]$} \\
Hemodialysis patients before dialysis procedure & $0.23 \mu \mathrm{g} / \mathrm{L}$ (median level) & {$[29]$}
\end{tabular}

ProCT-guided treatment reduced antibiotic use. This information was a very big gain for health professionals. One systemic review comprised 26 randomized clinical trials (RCTs) with 6708 patients, and suggested that ProCT-guided therapy for acute respiratory infections was associated with decreased antibiotic exposure (2-4 days) and side effects, and also improved survival [4]. It is well established that sepsis is a life-threatening disorder with a high mortality rate all over the world [16]. Early use of appropriate antibiotics is essential to reduce mortality. Non-specific inflammation and bacterial infections can be discriminated using the ProCT level, and recent guidelines and studies suggest that monitoring the ProCT level can be used as a prognostic factor to guide antimicrobial therapy and that ProCT-based antibiotic administration will decrease excessive antibiotic use and related side effects $[17,30,31]$. There are many studies with different results about ProCT-guided antimicrobial therapy. A meta-analysis composed of 13 trials with a total of 5136 patients showed that ProCT guided therapy resulted in de- creased antibiotic use (1.67 days) and lower short-term mortality rates. They concluded that ProCT monitoring could be used to guide the administration of antibiotherapy [32]. One of these studies noted that ProCT-based antibiotic administration reduced consumption of antibiotics by about $20 \%$ a year, and no significant influence was seen on mortality rate or length of hospitalization [17]. A ProCT level of $<0.5$ $\mu \mathrm{g} / \mathrm{L}$ in a case of systemic inflammatory response syndrome (SIRS) with no proof of infection or bacteremia can be supportive of discontinuing antibiotherapy [17]. A systematic review of clinical recommendations also suggested that ProCT monitoring decreased antibiotic use without affecting mortality, and the same study recommended that in intensive care units, antibiotic therapy could be discontinued when ProCT level decreased to $<0.5 \mu \mathrm{g} / \mathrm{L}$ or $80 \%$ [20]. Some studies about the relationship between ProCT level and survival rate have shown that the ProCT level is notably low in survivors even in early sepsis. A declining ProCT level in the first few days has been shown to be a predictor of mortal- 
ity $[17,33]$. A meta-analysis of 10 RCTs with 3489 patients demonstrated that ProCT monitoring with clinical evaluation resulted in a shorter duration of antibiotic use of about 1.5 days and demonstrated that ProCT use did not have a negative effect on mortality or duration of ICU stay [34]. Another study, a meta-analysis composed of 15 RCTs, also indicated that antibiotherapy guided by ProCT monitoring did not affect short-term mortality. In the same study, it was reported that ProCT-guided discontinuation of antibiotics decreased mortality and that PCT monitoring reduced the duration of antibiotherapy [35]. A meta-analysis consisting of 11 RCTs evaluated the effect of ProCT-guided antibiotic use in ICU patients with infection and demonstrated significantly low mortality for ProCT-guided antibiotic therapy in 2252 patients (in comparison with 2230 control patients). It also suggested that ProCT-guided therapy promoted earlier discontinuation of antibiotics and decreased the duration of the period of use [36].

One meta-analysis composed of 7 studies and including 1075 patients investigated ProCT-guided therapy in septic patients in the ICU. The study found no significant difference between the treatment guided by ProCT and standard management in the 28-day mortality rate. On the other hand, the length of antibiotic treatment was significantly reduced in the ProCT-guided group,. The study reported that ProCTguided therapy could be useful in shortening the duration of antibiotherapy [37].

One study that focused on ProCT use in critical care suggested that it resulted in less antibiotic exposure and that ProCT is a better biomarker for diagnosis in septic patients than C-reactive protein (CRP). The authors noted that there is the possibility of false-negative results, and recommended a repeat test in 6 to 12 hours. If all of the microbiological cultures are negative and a clear source of infection has not been determined in 24 hours, a repeat low PCT value, combined with clinical judgement, was considered strong reason to discontinue antimicrobial therapy. It was also noted that the ProCT level was correlated with the severity of sepsis and organ dysfunction [38]. One of the trials investigating daily ProCT measurements in 472 critically ill patients found that increased ProCT was associated with increased mortality, whereas CRP and white blood cell (WBC) count were not. Critical patients were defined by daily changes and high maximum levels, and ProCT increases (more than $1.0 \mu \mathrm{g} / \mathrm{L}$ ) for 1 day in the ICU was a predictor of 90 day mortality [39]. The ProCT level is also high in neonatal sepsis, and although both CRP and ProCT levels rise, the increase in ProCT is greater than that of CRP. A study that aimed to define the role of ProCT in neonatal sepsis and compare it with CRP evaluated 67 newborns with sepsis and found that while both become elevated, ProCT levels were more indicative than CRP in the earlier detection of neonatal sepsis and determination of the severity of illness and antibiotic response [40]. Similar studies in newborns have reported that ProCT was a useful marker for sepsis (especially compared with CRP) with high sensitivity and specificity rates [40-43].

\section{Established and new diagnostic markers in sepsis and cor- relation with procalcitonin}

Medical laboratories perform many conventional and new marker measurements. The test panels of laboratories are closely related to demands from clinics, budgets of hospitals, staff, availability of high-tech tools, and workload. There is a lot of information in the current medical literature related to ProCT and sepsis as well as other new or established biomarkers (Table 3). One of the most frequently used markers in routine practice is undoubtedly a measure of CRP. CRP, which can become elevated with infection, inflammation, and trauma, is an acute-phase protein secreted by the liver. The CRP level may rise to more than 1000 times than normal after infection or trauma [44]. ProCT and CRP are the most preferable tests in sepsis [45]. Zhang et al. [46] studied ProCT and high-sensitivity CRP (hs-CRP) levels in the evaluation of sepsis and septic shock in geriatric patients in the ICU. They found that hs-CRP and ProCT were good markers for the diagnosis of sepsis and septic shock in patients who were older than 85 years of age. Garnacho-Montero et al. [45] researched ProCT and CRP levels in SIRS and they concluded that ProCT can be a more dependable biomarker upon admission to hospital and was considered superior to the CRP value.

In addition to CRP, lactate is a good marker for organ dysfunction and may increase in septic shock [15]. A high lactate level is strongly associated with high mortality [47]. Shapiro et al. [48] researched serum lactate levels and the risk of death in 1278 emergency department patients with infection. They found that lactate can be a predictor of mortality [48]. Phua et al. [49] investigated serum ProCT, lactate, amino-terminal pro-B-type natriuretic peptide, and cytokine values for prognostic evaluation of septic shock in 82 patients. They concluded that elevated baseline lactate level were superior to ProCT levels for prognostic evaluation in septic shock patients [49].

Cytokines are produced by the immune system in response to inflammation or infection. Kellum et al. [50] studied interleukin 6 (IL-6), IL10, and tumor necrosis factor a (TNF-a) in septic patients and they found that cytokine levels were elevated in severe sepsis and that the highest risk of death was a combined high level of IL- 6 and IL-10. Andaluz-Ojeda et al. [51] measured 20 different cytokines in severe sepsis patients and found that high levels of IL-6, IL-8, IL-10, and monocyte chemoattractant protein 1 were predictors of mortality.

Cluster of differentiation 64 (CD64), which is a surface marker of circulating neutrophils, is a high affinity receptor for immunoglobulin G. Ng et al. [52] studied CD64 in 338 infants with suspected sepsis. They found that CRP and CD 64 levels were high in infected group. They also concluded that CD64 had a very high sensitivity (96\%). Livaditi et al. [53] investigated CD64, ProCT, CRP, IL-6, IL-8, IL-10, IL-1 $\beta$, IL-12p70, and TNF-a in 47 patients who were within 24 hours of septic onset. They found that CD64 and IL-8 demonstrated an early enhancement during sepsis and increased with sepsis severity. 
Table 3. Features of newer and well-established markers

\begin{tabular}{|c|c|c|c|c|}
\hline Marker & $\begin{array}{l}\text { Specific feature and relationship } \\
\text { to sepsis }\end{array}$ & Relationship to ProCT & Measurement Methods & Reference \\
\hline CRP & $\begin{array}{l}\text { CRP level measurement and } \\
\text { monitoring is useful during sepsis } \\
\text { and sepsis treatment }\end{array}$ & $\begin{array}{l}\text { ProCT and CRP levels were good markers } \\
\text { for predicting outcome in sepsis and septic } \\
\text { shock }\end{array}$ & $\begin{array}{l}\text { Immunoturbidometric } \\
\text { assay }\end{array}$ & {$[46,61-64]$} \\
\hline Lactate & $\begin{array}{l}\text { Lactate is a promising biomarker for } \\
\text { organ dysfunction }\end{array}$ & $\begin{array}{l}\text { Elevated baseline lactate was superior to } \\
\text { ProCT level for prognostic evaluation in } \\
\text { septic shock }\end{array}$ & Photometry & [49] \\
\hline IL-6 & Pro-inflammatory cytokine & $\begin{array}{l}\text { ProCT had better diagnostic performance } \\
\text { than IL-6 }\end{array}$ & $\begin{array}{l}\text { Chemiluminescent } \\
\text { immunometric assay }\end{array}$ & [65-67] \\
\hline IL-8 & Chemokine & $\begin{array}{l}\text { ProCT had greater discriminative value than } \\
\text { IL-8 }\end{array}$ & $\begin{array}{l}\text { Chemiluminescent } \\
\text { immunometric assay }\end{array}$ & [66] \\
\hline IL-10 & Anti-inflammatory cytokine & $\begin{array}{l}\text { Plasma ProCT and IL-10 concentrations were } \\
\text { higher in non-survivors than in survivors } \\
\text { among septic patients }\end{array}$ & $\begin{array}{l}\text { Chemiluminescent } \\
\text { immunometric assay }\end{array}$ & [68] \\
\hline CD64 & $\begin{array}{l}\text { A surface biomarker of circulating } \\
\text { neutrophils and a high affinity } \\
\text { receptor for immunoglobulin G }\end{array}$ & $\begin{array}{l}\text { ProCT levels and CD64 index were greater in } \\
\text { septic patients compared with controls. CD } 64 \\
\text { index was an independent predictor of sepsis }\end{array}$ & Flow cytometry & {$[71,72]$} \\
\hline Presepsin & $\begin{array}{l}\text { Soluble CD14-subtype is called } \\
\text { presepsin. }\end{array}$ & $\begin{array}{l}\text { The diagnostic accuracy of presepsin was } \\
\text { greater than ProCT in neonatal sepsis }\end{array}$ & $\begin{array}{l}\text { Chemiluminescence } \\
\text { enzyme immunoassay }\end{array}$ & {$[73,74]$} \\
\hline sTREM-1 & $\begin{array}{l}\text { STREM-1 is a biomarker of sepsis } \\
\text { severity }\end{array}$ & $\begin{array}{l}\text { ProCT, IL-6, sTREM-1, and sCD163 were } \\
\text { correlated with SOFA score }\end{array}$ & $\begin{array}{l}\text { Sandwich enzyme-linked } \\
\text { immunosorbent assay, } \\
\text { Luminex assay }\end{array}$ & [60] \\
\hline LBP & $\begin{array}{l}\text { Produced by liver as acute phase } \\
\text { inflammatory response }\end{array}$ & $\begin{array}{l}\text { LBP was superior to ProCT as a diagnostic } \\
\text { biomarker for sepsis }\end{array}$ & $\begin{array}{l}\text { Chemiluminescent } \\
\text { immunometric assay }\end{array}$ & [75] \\
\hline ProADM & $\begin{array}{l}\text { ProADM is a vasodilatator in the } \\
\text { calcitonin peptide superfamily with } \\
\text { ProCT }\end{array}$ & $\begin{array}{l}\text { ProADM was superior to ProCT in sepsis } \\
\text { (ProADM AUC: } 0.72 ; \text { ProCT AUC: } 0.4 \text { ) }\end{array}$ & Sandwich immunoassay & [76] \\
\hline MIF & $\begin{array}{l}\text { MIF has a chemokine-like function } \\
\text { that can be produced by monocytes, } \\
\text { macrophages, B cells, and T cells }\end{array}$ & $\begin{array}{l}\text { ProCT was a superior diagnostic marker } \\
\text { compared with MIF }\end{array}$ & ELISA, Luminex assay & [79] \\
\hline SUPAR & $\begin{array}{l}\text { SuPAR, which is considered as } \\
\text { the soluble form of urokinase- } \\
\text { type plasminogen (uPAR), can be } \\
\text { produced under inflammatory } \\
\text { stimulation and/or immune system } \\
\text { activation. }\end{array}$ & $\begin{array}{l}\text { Use of a combination of suPAR and ProCT } \\
\text { improved the strength for sepsis diagnosis }\end{array}$ & ELISA, Luminex assay & [80] \\
\hline D-dimer & Product of fibrin degradation. & $\begin{array}{l}\text { The discriminatory ability of D-dimer for } \\
\text { sepsis was greater than that of ProCT }\end{array}$ & $\begin{array}{l}\text { Immuno-turbidimetric } \\
\text { assay }\end{array}$ & {$[81,82]$} \\
\hline Amyloid P & $\begin{array}{l}\text { Serum amyloid } P \text { is member of } \\
\text { the pentraxin family and regulates } \\
\text { inflammation }\end{array}$ & $\begin{array}{l}\text { Serum amyloid } \mathrm{P} \text { and tissue plasminogen } \\
\text { activator demonstrated the best individual } \\
\text { predictive performance for mortality }\end{array}$ & $\begin{array}{l}\text { Nephelometric assays, } \\
\text { ELISA }\end{array}$ & [83] \\
\hline Endotoxin activity & $\begin{array}{l}\text { Key component of the membrane of } \\
\text { Gram-negative bacteria }\end{array}$ & $\begin{array}{l}\text { ProCT and endotoxin levels rise in severe } \\
\text { sepsis }\end{array}$ & Chemiluminescent assay & {$[84,85]$} \\
\hline
\end{tabular}

AUC: Area under curve; CRP: C-reactive protein; IL: Interleukin; ELISA: Enzyme-linked immunosorbent assay; LBP: Lipopolysaccharide binding protein; MIF: Macrophage migration inhibitory factor; ProADM: Proadrenomedullin; ProCT: Procalcitonin; PTX3: Pentraxin 3; SOFA: Sequential organ failure assessment; sTREM-1: Soluble triggering receptor expressed on myeloid cells-1; suPAR: Soluble urokinase-type plasminogen activator receptor; uPAR: Urokinase-type plasminogen. 
There are several other studies that have investigated the significance of CD64 in sepsis [54-57].

CD14 is the receptor for lipopolysaccharide (LPS) and LPS-binding protein (LPS-BP) complexes. There are 2 forms of CD14: a soluble form (sCD14) and a membrane form (mCD14). LPS-LPS$\mathrm{BP}-\mathrm{CD} 14$ is released into the circulation and plasma protease activity generates the sCD14-subtype (sCD14-ST) called presepsin. Ulla et al. [58] studied presepsin and ProCT and found elevated presepsin and ProCT levels in sepsis. The diagnostic accuracy was higher for ProCT compared with presepsin (area under the curve: 0.875 for ProCT, 0.701 for presepsin). In the Albumin Italian Outcome Sepsis (ALBIOS) trial, presepsin was measured in 997 patients with severe sepsis or septic shock. They found that presepsin levels increased with the sequential organ failure assessment (SOFA) score and they concluded that presepsin was an early indicator of mortality in septic patients [59]. Rios-Toro et al. [60] researched ProCT, CRP, the soluble triggering receptor expressed on myeloid cell 1 (sTREM-1), sCD14, sCD163, IL-6 serum levels, and the SOFA and Acute Physiology And Chronic Health Evaluation (APACHE) III scores in patients with sepsis or septic shock. They found that baseline serum concentrations of ProCT, IL-6, sTREM-1, and SCD163 correlated well with the SOFA score and that sTREM-1 levels correlated with the APACHE II score.

\section{Challenges and future aspects}

An ideal sepsis biomarker would be measurable even during the early symptoms, cost-effective, very sensitive and specific to infections in order to establish a definitive differential diagnosis between infectious and noninfectious diseases, informative about the clinical course and/or provide valuable information about prognosis [86]. Unfortunately, none of the aforementioned biomarkers can fulfill all of those criteria alone. ProCT is not a miraculous magic wand test either. To overcome this issue, some researchers have suggested that biomarkers could be used together in a sepsis panel. Dolin et al. [87] proposed the use of ProCT, IL-6, and sTREM-1 as biomarkers for the diagnosis of early-phase sepsis. Yaguchi et al. [88] suggested combining ProCT and WBC in intermediate endotoxin activity levels to diagnose sepsis. Gibot et al. [89] demonstrated the high performance of ProCT, CD64 index, and sTREM-1 levels in diagnosing sepsis. Among the markers in Table 3, CD64, IL 27, lipopolysaccharide-binding protein, proadrenomedulin, hepcidin, and presepsin are promising for the diagnosis of sepsis. In conclusion, ProCT is a useful marker for sepsis, and monitoring the ProCT level in combination with clinical judgement can prevent unnecessary antibiotic use in septic patients. Nonetheless, the development of additional easier, less labor-intensive measurement methods, less expensive and faster methods, and the establishment of reference ranges for different races, altitudes, and even for different biological samples according to the concept of personalized medicine, are all necessary.

Acknowledgment: We would like to note that there are a number of other excellent and distinctive studies about ProCT that we could not cite in this publication. We also want to thank our valuable laboratory technicians for their wonderful and immeasurable contributions to routine ProCT measurement in laboratories everywhere.

\section{Conflict of Interest: None declared.}

Financial Disclosure: None declared.

Peer-review: Externally peer-reviewed.

\section{References}

1. Kaufmann SH. Immunology's foundation: the 100-year anniversary of the Nobel Prize to Paul Ehrlich and Elie Metchnikoff. Nat Immunol 2008;9:705-12. [CrossRef]

2. Brachman PS. Infectious diseases--past, present, and future. Int J Epidemiol 2003;32:684-6. [CrossRef]

3. Blair JMA. A climate for antibiotic resistance. Nature Climate Change 2018;8:460-1. [CrossRef]

4. Merker M, Bolliger R, Schuetz P. Procalcitonin-guided decisionmaking results in a significant reduction of antibiotic therapy and hospital stay in neonates with suspected early-onset sepsis. BMJ Evid Based Med 2018;23:154-5. [CrossRef]

5. Ghillani PP, Motté P, Troalen F, Jullienne A, Gardet P, Le Chevalier $T$, et al. Identification and measurement of calcitonin precursors in serum of patients with malignant diseases. Cancer Res 1989;49:6845-51.

6. Assicot M, Gendrel D, Carsin H, Raymond J, Guilbaud J, Bohuon $\mathrm{C}$. High serum procalcitonin concentrations in patients with sepsis and infection. Lancet 1993;341:515-8. [CrossRef]

7. Moya F, Nieto A, R-Candela JL. Calcitonin biosynthesis: evidence for a precursor. Eur J Biochem 1975;55:407-13. [CrossRef]

8. Roos BA, Okano K, Deftos LJ. Evidence for a pro-calcitonin. Biochem Biophys Res Commun 1974;60:1134-40. [CrossRef]

9. Bertagna $X Y$, Nicholson WE, Pettengill OS, Sorenson GD, Mount CD, Orth DN. Ectopic production of high molecular weight calcitonin and corticotropin by human small cell carcinoma cells in tissue culture: evidence for separate precursors. $J$ Clin Endocrinol Metab 1978;47:1390-3. [CrossRef]

10. Le Moullec JM, Jullienne A, Chenais J, Lasmoles F, Guliana JM, Milhaud $\mathrm{G}$, et al. The complete sequence of human preprocalcitonin. FEBS Lett 1984;167:93-7. [CrossRef]

11. Birnbaum RS, Mahoney WC, Burns DM, O'Neil JA, Miller RE, Roos BA. Identification of procalcitonin in a rat medullary thyroid carcinoma cell line. J Biol Chem 1984;259:2870-4.

12. Dandona P, Nix D, Wilson MF, Aljada A, Love J, Assicot M, et al. Procalcitonin increase after endotoxin injection in normal subjects. J Clin Endocrinol Metab 1994;79:1605-8. [CrossRef]

13. Gendrel D, Assicot M, Raymond J, Moulin F, Francoual C, Badoual J, et al. Procalcitonin as a marker for the early diagnosis of neonatal infection. J Pediatr 1996;128:570-3. [CrossRef]

14. Gérard Y, Hober D, Assicot M, Alfandari S, Ajana F, Bourez JM, et al. Procalcitonin as a marker of bacterial sepsis in patients infected with HIV-1. J Infect 1997;35:41-6. [CrossRef]

15. Singer $M$, Deutschman CS, Seymour CW, Shankar-Hari $M$, Annane $D$, Bauer $M$, et al. The Third International Consen- 
sus Definitions for Sepsis and Septic Shock (Sepsis-3). JAMA 2016;315:801-10. [CrossRef]

16. Tan $M$, Lu Y, Jiang $H$, Zhang L. The diagnostic accuracy of procalcitonin and C-reactive protein for sepsis: A systematic review and meta-analysis. J Cell Biochem 2019;120:5852-9. [CrossRef]

17. Rojas-Moreno C, Regunath $\mathrm{H}$. Procalcitonin in Sepsis. Journal of Academic Hospital Medicine 2016;8.

18. Charles PE, Ladoire S, Aho S, Quenot JP, Doise JM, Prin S, et al. Serum procalcitonin elevation in critically ill patients at the onset of bacteremia caused by either Gram negative or Gram positive bacteria. BMC Infect Dis 2008;8:38. [CrossRef]

19. Brodská H, Malíčková K, Adámková V, Benáková H, Štastná MM, Zima T. Significantly higher procalcitonin levels could differentiate Gram-negative sepsis from Gram-positive and fungal sepsis. Clin Exp Med 2013;13:165-70. [CrossRef]

20. Schuetz P, Chiappa V, Briel M, Greenwald JL. Procalcitonin algorithms for antibiotic therapy decisions: a systematic review of randomized controlled trials and recommendations for clinical algorithms. Arch Intern Med 2011;171:1322-31. [CrossRef]

21. Wiedermann FJ, Kaneider N, Egger P, TiefenthalerW, Wiedermann $\mathrm{CJ}$, Lindner $\mathrm{KH}$, et al. Migration of human monocytes in response to procalcitonin. Crit Care Med 2002;30:1112-7. [CrossRef]

22. Liu HH, Guo JB, Geng Y, Su L. Procalcitonin: present and future. Ir J Med Sci 2015;184:597-605. [CrossRef]

23. Dwolatzky T, Olshtain-Pops K, Yinnon AM, Raveh D, Rogowski $\mathrm{O}$, Shapira I, et al. Procalcitonin in the elderly: normal plasma concentrations and response to bacterial infections. Eur J Clin Microbiol Infect Dis 2005;24:763-5. [CrossRef]

24. Hu Y, Yang M, Zhou Y, Ding Y, Xiang Z, Yu L. Establishment of reference intervals for procalcitonin in healthy pregnant women of Chinese population. Clin Biochem 2017;50:1504. [CrossRef]

25. Chiesa C, Natale F, Pascone R, Osborn JF, Pacifico L, Bonci E, et al. $C$ reactive protein and procalcitonin: reference intervals for preterm and term newborns during the early neonatal period. Clin Chim Acta 2011;412:1053-9. [CrossRef]

26. Lee JY, Hwang SJ, Shim JW, Jung HL, Park MS, Woo HY, et al. Clinical significance of serum procalcitonin in patients with community-acquired lobar pneumonia. Korean J Lab Med 2010;30:406-13. [CrossRef]

27. Enguix-Armada A, Escobar-Conesa R, García-De La Torre A, De La Torre-Prados MV. Usefulness of several biomarkers in the management of septic patients: C-reactive protein, procalcitonin, presepsin and mid-regional pro-adrenomedullin. Clin Chem Lab Med 2016;54:163-8. [CrossRef]

28. Lai CC, Chen SY, Wang CY, Wang JY, Su CP, Liao CH, et al. Diagnostic value of procalcitonin for bacterial infection in elderly patients in the emergency department. J Am Geriatr Soc 2010;58:518-22. [CrossRef]

29. Kubo S, Iwasaki M, Horie M, Matsukane A, Hayashi T, Tanaka Y, et al. Biological variation of procalcitonin levels in hemodialysis patients. Clin Exp Nephrol 2019;23:402-8. [CrossRef]

30. Branche A, Neeser O, Mueller B, Schuetz P. Procalcitonin to guide antibiotic decision making. Curr Opin Infect Dis 2019;32:130-5. [CrossRef]
31. Nunnally ME, Patel A. Sepsis - What's new in 2019? Curr Opin Anaesthesiol 2019;32:163-8. [CrossRef]

32. Huang HB, Peng JM, Weng L, Wang CY, Jiang W, Du B. Procalcitonin-guided antibiotic therapy in intensive care unit patients: a systematic review and meta-analysis. Ann Intensive Care 2017;7:114. [CrossRef]

33. Arora S, Singh P, Singh PM, Trikha A. Procalcitonin Levels in Survivors and Nonsurvivors of Sepsis: Systematic Review and Meta-Analysis. Shock 2015;43:212-21. [CrossRef]

34. lankova I, Thompson-Leduc P, Kirson NY, Rice B, Hey J, Krause $\mathrm{A}$, et al. Efficacy and Safety of Procalcitonin Guidance in Patients With Suspected or Confirmed Sepsis: A Systematic Review and Meta-Analysis. Crit Care Med 2018;46:691-8. [CrossRef]

35. Lam SW, Bauer SR, Fowler R, Duggal A. Systematic Review and Meta-Analysis of Procalcitonin-Guidance Versus Usual Care for Antimicrobial Management in Critically III Patients: Focus on Subgroups Based on Antibiotic Initiation, Cessation, or Mixed Strategies. Crit Care Med 2018;46:684-90. [CrossRef]

36. Wirz Y, Meier MA, Bouadma L, Luyt CE, Wolff M, Chastre J, et al. Effect of procalcitonin-guided antibiotic treatment on clinical outcomes in intensive care unit patients with infection and sepsis patients: a patient-level meta-analysis of randomized trials. Crit Care 2018;22:191. [CrossRef]

37. Prkno A, Wacker C, Brunkhorst FM, Schlattmann P. Procalcitonin-guided therapy in intensive care unit patients with severe sepsis and septic shock-a systematic review and meta-analysis. Crit Care 2013;17:R291. [CrossRef]

38. Kibe S, Adams K, Barlow G. Diagnostic and prognostic biomarkers of sepsis in critical care. J Antimicrob Chemother 2011;66 Suppl 2:ii33-40. [CrossRef]

39. Jensen JU, Heslet L, Jensen TH, Espersen K, Steffensen P, Tvede $M$. Procalcitonin increase in early identification of critically ill patients at high risk of mortality. Crit Care Med 2006;34:2596-602.

40. Köksal N, Harmanci R, Cetinkaya M, Hacimustafaoğlu M. Role of procalcitonin and CRP in diagnosis and follow-up of neonatal sepsis. Turk J Pediatr 2007;49:21-9.

41. Janota J, Stranák Z, Bĕlohlávková S, Mudra K, Simák J. Postnatal increase of procalcitonin in premature newborns is enhanced by chorioamnionitis and neonatal sepsis. Eur J Clin Invest 2001;31:978-83. [CrossRef]

42. Shah BA, Padbury JF. Neonatal sepsis: an old problem with new insights. Virulence 2014;5:170-8. [CrossRef]

43. Delanghe JR, Speeckaert MM. Translational research and biomarkers in neonatal sepsis. Clin Chim Acta 2015;451:46-64.

44. Morley JJ, Kushner I. Serum C-reactive protein levels in disease. Ann N Y Acad Sci 1982;389:406-18. [CrossRef]

45. Garnacho-Montero J, Huici-Moreno MJ, Gutiérrez-Pizarraya A, López I, Márquez-Vácaro JA, Macher H, et al. Prognostic and diagnostic value of eosinopenia, C-reactive protein, procalcitonin, and circulating cell-free DNA in critically ill patients admitted with suspicion of sepsis. Crit Care 2014;18:R116. [CrossRef] 46. Zhang H, Wang X, Zhang Q, Xia Y, Liu D. Comparison of procalcitonin and high-sensitivity $\mathrm{C}$-reactive protein for the diagnosis of sepsis and septic shock in the oldest old patients. BMC Geriatr 2017;17:173 [CrossRef] 
47. Fan SL, Miller NS, Lee J, Remick DG. Diagnosing sepsis - The role of laboratory medicine. Clin Chim Acta 2016;460:20310. [CrossRef]

48. Shapiro NI, Howell MD, Talmor D, Nathanson LA, Lisbon A, Wolfe RE, et al. Serum lactate as a predictor of mortality in emergency department patients with infection. Ann Emerg Med 2005;45:524-8. [CrossRef]

49. Phua J, Koay ES, Lee KH. Lactate, procalcitonin, and aminoterminal pro-B-type natriuretic peptide versus cytokine measurements and clinical severity scores for prognostication in septic shock. Shock 2008;29:328-33. [CrossRef]

50. Kellum JA, Kong L, Fink MP, Weissfeld LA, Yealy DM, Pinsky $M R$, et al. Understanding the inflammatory cytokine response in pneumonia and sepsis: results of the Genetic and Inflammatory Markers of Sepsis (GenIMS) Study. Arch Intern Med 2007;167:1655-63. [CrossRef]

51. Andaluz-Ojeda D, Bobillo F, Iglesias V, Almansa R, Rico L, Gandía F, et al. A combined score of pro- and anti-inflammatory interleukins improves mortality prediction in severe sepsis. Cytokine 2012;57:332-6. [CrossRef]

52. Ng PC, Li G, Chui KM, Chu WC, Li K, Wong RP, et al. Neutrophil CD64 is a sensitive diagnostic marker for early-onset neonatal infection. Pediatr Res 2004;56:796-803. [CrossRef]

53. Livaditi O, Kotanidou A, Psarra A, Dimopoulou I, Sotiropoulou C, Augustatou K, et al. Neutrophil CD64 expression and serum IL-8: sensitive early markers of severity and outcome in sepsis. Cytokine 2006;36:283-90. [CrossRef]

54. Bhandari V, Wang C, Rinder C, Rinder H. Hematologic profile of sepsis in neonates: neutrophil CD64 as a diagnostic marker. Pediatrics 2008;121:129-34. [CrossRef]

55. Ng PC, Li K, Wong RP, Chui KM, Wong E, Fok TF. Neutrophil CD64 expression: a sensitive diagnostic marker for late-onset nosocomial infection in very low birthweight infants. Pediatr Res 2002;51:296-303. [CrossRef]

56. Streimish I, Bizzarro M, Northrup V, Wang C, Renna S, Koval N, et al. Neutrophil CD64 as a diagnostic marker in neonatal sepsis. Pediatr Infect Dis J 2012;31:777-81. [CrossRef]

57. Farias MG, de Lucena NP, Dal Bó S, de Castro SM. Neutrophil CD64 expression as an important diagnostic marker of infection and sepsis in hospital patients. J Immunol Methods 2014;414:65-8. [CrossRef]

58. Ulla M, Pizzolato E, Lucchiari M, Loiacono M, Soardo F, Forno $D$, et al. Diagnostic and prognostic value of presepsin in the management of sepsis in the emergency department: a multicenter prospective study. Crit Care 2013;17:R168. [CrossRef]

59. Masson S, Caironi P, Fanizza C, Thomae R, Bernasconi R, Noto A, et al. Circulating presepsin (soluble CD14 subtype) as a marker of host response in patients with severe sepsis or septic shock: data from the multicenter, randomized ALBIOS trial. Intensive Care Med 2015;41:12-20. [CrossRef]

60. Ríos-Toro JJ, Márquez-Coello M, García-Álvarez JM, MartínAspas A, Rivera-Fernández R, Sáez de Benito A, et al. Soluble membrane receptors, interleukin 6 , procalcitonin and $C$ reactive protein as prognostic markers in patients with severe sepsis and septic shock. PLoS One 2017;12:e0175254. [CrossRef]
61. Ryu JA, Yang JH, Lee D, Park CM, Suh GY, Jeon K, et al. Clinical Usefulness of Procalcitonin and C-Reactive Protein as Outcome Predictors in Critically III Patients with Severe Sepsis and Septic Shock. PLoS One 2015;10:e0138150. [CrossRef]

62. Póvoa P, Almeida E, Moreira P, Fernandes A, Mealha R, Aragão $A$, et al. C-reactive protein as an indicator of sepsis. Intensive Care Med 1998;24:1052-6. [CrossRef]

63. Yentis SM, Soni N, Sheldon J. C-reactive protein as an indicator of resolution of sepsis in the intensive care unit. Intensive Care Med 1995;21:602-5. [CrossRef]

64. Parlato M, Philippart F, Rouquette A, Moucadel V, Puchois V, Blein $S$, et al. Circulating biomarkers may be unable to detect infection at the early phase of sepsisin ICU patients: the CAPTAIN prospective multicenter cohort study. Intensive Care Med 2018;44:1061-70. [CrossRef]

65. Jekarl DW, Lee SY, Lee J, Park YJ, Kim Y, Park JH, et al. Procalcitonin as a diagnostic marker and IL- 6 as a prognostic marker for sepsis. Diagn Microbiol Infect Dis 2013;75:342-7. [CrossRef]

66. Harbarth S, Holeckova K, Froidevaux C, Pittet D, Ricou B, Grau $\mathrm{GE}$, et al. Diagnostic value of procalcitonin, interleukin-6, and interleukin-8 in critically ill patients admitted with suspected sepsis. Am J Respir Crit Care Med 2001;164:396-402. [CrossRef]

67. Nainggolan SC, Aman AK, Hanafie A. The Relationship Between The Level Of Interleukin-6 And Procalcitonin In Severe Sepsis Patients At The Adam Malik Hospital. Indonesian Journal of Clinical Pathology And Medical Laboratory 2019;25:38-41.

68. Wunder C, Eichelbrönner O, Roewer N. Are IL-6, IL-10 and PCT plasma concentrations reliable for outcome prediction in severe sepsis? A comparison with APACHE III and SAPS II. Inflamm Res 2004;53:158-63. [CrossRef]

69. Wong HR, Cvijanovich NZ, Hall M, Allen GL, Thomas NJ, Freishtat RJ, et al. Interleukin-27 is a novel candidate diagnostic biomarker for bacterial infection in critically ill children. Crit Care 2012;16:R213. [CrossRef]

70. Hanna WJ, Berrens Z, Langner T, Lahni P, Wong HR. Interleukin-27: a novel biomarker in predicting bacterial infection among the critically ill. Crit Care 2015;19:378. [CrossRef]

71. Thiriet C, Mahjoub K, Courte G, Labroca P, Cravoisy A, Lemarie $J$, et al. Automated measurement of neutrophil CD64 expression for diagnosing sepsis in critically ill patients. Minerva Anestesiol 2019;85:943-50. [CrossRef]

72. Yeh CF, Wu CC, Liu SH, Chen KF. Comparison of the accuracy of neutrophil CD64, procalcitonin, and C-reactive protein for sepsis identification: a systematic review and meta-analysis. Ann Intensive Care 2019;9:5. [CrossRef]

73. Kumar N, Dayal R, Singh P, Pathak S, Pooniya V, Goyal A, et al. A Comparative Evaluation of Presepsin with Procalcitonin and CRP in Diagnosing Neonatal Sepsis. Indian J Pediatr 2019;86:177-9. [CrossRef]

74. Iskandar A, Arthamin MZ, Indriana K, Anshory M, Hur M, Di Somma S; GREAT Network. Comparison between presepsin and procalcitonin in early diagnosis of neonatal sepsis. J Matern Fetal Neonatal Med 2019;32:3903-8. [CrossRef]

75. Gaïni S, Koldkjaer OG, Pedersen C, Pedersen SS. Procalcitonin, lipopolysaccharide-binding protein, interleukin-6 and C-re- 
active proteinin community-acquired infections and sepsis: a prospective study. Crit Care 2006;10:R53. [CrossRef]

76. Suberviola B, Castellanos-Ortega A, Llorca J, Ortiz F, Iglesias $D$, Prieto $B$. Prognostic value of proadrenomedullin in severe sepsis and septic shock patients with community-acquired pneumonia. Swiss Med Wkly 2012;142:w13542. [CrossRef]

77. Qiu Z, Shen K, Shu M, Xu D, Deng X, Chen D. Value of Hepcidin as a diagnostic biomarker of sepsis in critically ill adults. [Article in Chinese]. Zhonghua Wei Zhong Bing Ji Jiu Yi Xue 2018;30:652-7.

78. Uusitalo-Seppälä R, Huttunen R, Aittoniemi J, Koskinen P, Leino A, Vahlberg T, et al. Pentraxin 3 (PTX3) is associated with severe sepsis and fatal disease in emergency room patients with suspected infection: a prospective cohort study. PLoS One 2013;8:e53661. [CrossRef]

79. Kofoed K, Andersen O, Kronborg G, Tvede M, Petersen J, Eugen-Olsen J, et al. Use of plasma C-reactive protein, procalcitonin, neutrophils, macrophage migration inhibitory factor, soluble urokinase-type plasminogen activator receptor, and soluble triggering receptor expressed on myeloid cells- 1 in combination to diagnose infections: a prospective study. Crit Care 2007; 11:R38. [CrossRef]

80. Zeng M, Chang M, Zheng H, Li B, Chen Y, He W, et al. Clinical value of soluble urokinase-type plasminogen activator receptor in the diagnosis, prognosis, and therapeutic guidance of sepsis. Am J Emerg Med 2016;34:375-80. [CrossRef]

81. Kinasewitz GT, Yan SB, Basson B, Comp P, Russell JA, Cariou $A$, et al. Universal changes in biomarkers of coagulation and inflammation occur in patients with severe sepsis, regardless of causative micro-organism [ISRCTN74215569]. Crit Care 2004;8:R82-90. [CrossRef]

82. Rodelo JR, De la Rosa G, Valencia ML, Ospina S, Arango CM, Gómez $\mathrm{Cl}$, et al. D-dimer is a significant prognostic factor in patients with suspected infection and sepsis. Am J Emerg Med 2012;30:1991-9. [CrossRef]

83. Kelly BJ, Lautenbach E, Nachamkin I, Coffin SE, Gerber JS, Fuchs BD, et al. Combined Biomarkers Predict Acute Mortality Among Critically III Patients With Suspected Sepsis. Crit Care Med 2018;46:1106-13. [CrossRef]

84. Foster D, Romaschin A, Derzko A, Walker P. Rates of agreement of endotoxin, procalcitonin and lactate in septic and non-septic critically ill patients. Crit Care 2005;9:P162. [CrossRef]

85. Saito N, Kang M, Saito M, Tsunoda M, Namiki M, Yuzawa J, et al. 635: The Utility Of Endotoxin Activity Assay For The Diagnosis Of Gram-negative Infection. Critical Care Medicine 2019;47:298.

86. Lippi G. Sepsis biomarkers: past, present and future. Clin Chem Lab Med 2019;57:1281-3. [CrossRef]

87. Dolin HH, Papadimos TJ, Stepkowski S, Chen X, Pan ZK. A Novel Combination of Biomarkers to Herald the Onset of Sepsis Prior to the Manifestation of Symptoms. Shock 2018;49:364-70. [CrossRef]

88. Yaguchi A, Yuzawa J, Klein DJ, Takeda M, Harada T. Combining intermediate levels of the Endotoxin Activity Assay (EAA) with otherbiomarkers in the assessment of patients with sepsis: results of an observational study. Crit Care 2012;16:R88. [CrossRef]

89. Gibot S, Béné MC, Noel R, Massin F, Guy J, Cravoisy A, et al. Combination biomarkers to diagnose sepsis in the critically ill patient. Am J Respir Crit Care Med 2012;186:65-71. [CrossRef] 